\title{
ECOLOGICAL SAFETY OF THE CARPATHIAN REGION AS A PROCESS OF OIL AND GAS COMPLEXES FUNCTIONING
}

\author{
GEORGIY RUDKO*
}

\begin{abstract}
There have been considered the main ecological problems of Western Ukraine and changes of geological environment under the influence of oil and gas complexes functioning. Ecochemical investigations of the environment give us a possibility to reveal the areas with abnormal hydrocarbon concentration in the nearsurface layers and in ground waters. On the basis of the investigation results there have been worked out organizational, technological and environmental measures to eliminate pollution or to reduce its negative influence on geological environment.
\end{abstract}

Western Ukraine is the region with the highly developed infrastructure of recovery, transportation, refining and consumption of oil, petroleum products and gas. There has been developed a big net of transit and local pipelines for oil and gas products, refineries, big stations for storage and refinery of oil, gas and their products. Due to this the geological environment on certain areas has a great ecological loading, the influence of which is frequently appeared as a result of systematic and emergency losses of oil and oil products. Their spreading and filtration through the aeration zone cause a complicated process of landscape pollution: superficial shutes, the upper zone of soil (including zone of saturated filtration and groundwaters), creating stable petrochemical pollution sources for the natural environment. The majority of the revealed pollution sources have a great number of oil products. The main sources of the long-lasting petrochemical pollution of the natural environment are the objects of the petrochemical complex (PCC), where annual losses of oil and oil products caused by different emergencies come to thousands of tons. Moreover there can be observed a tendency of increasing the number of emergencies and losses of oil and oil products due to complex influence of technogenous (man-caused) disturbances of the engineering- hydro-geological conditions (activation of exogenous geological processes) and equipment wearability. The number of oil products, that are annually carried out from the pollution sources by superficial water, is more than thousands tons.

The systematic losses are also spread at the objects of petrochemical complex. As a rule they are prolonged, dimensioned as to their development and assessment and create conditions for the objectionable geological consequences, which exceed considerably the risk of disastrous effects. They namely determine the permanent existence of sources of petrochemical pollution of soil and

\footnotetext{
* Ivano-Frankivsk National Technical University of Oil and Gas
} 
groundwater that have been recently revealed. Petrochemical pollution poses a big threat for the system of water supply (economic and potable). It is determined by rather penetrating sandy-argillaceous rocks that are not practically protected from the surface and this, in its turn, makes it complicated (difficult) to foresee the "hidden" pollution caused by oil products.

The western region of Ukraine (Precarpathia) is characterized by a heightened sensibility to the technogenous influence of the objects of PCC.

During oil exploration on the certain areas, where there has been built exploration drill holes, the chemical composition of groundwater, superficial water and soil has endured considerable changes. There has been determined that groundwater and surface water are polluted by oil products, highly mineralized sewage water and surface-active substances. The areas of contamination halation and penetration depth are different depending on duration and hydrogeological conditions, the quality of environmental measures, etc.

In many petroliferous districts of the Precarpathia mining operations have begun since the second part of the last century (Boryslavske field, Bytkivske field, Skhidnytske field and others). The recovery was done with the help of pits, and then wells drilled by way of percussion drilling and later by way of rotary drilling. According to the incomplete data, within the town Borislav there can be found more than 20 thousand abandoned pits and nearly 2160 oil wells. In the majority of wells, drilled before 1938, the casing strings were not cemented and as the result the well sealing was broken (destroyed). Such condition helps hydrocarbon in liquid and gaseous state to flow from productive oil and gas bearing beds to the higher ones, namely, to the overburden. Besides, there are several mines and 340 exploration wax holes, the abandonment of which has been done with the violation of process requirements. As the result gas gryphons can be observed nearby.

The development of Bytkiv oil industry began in the $60^{\text {th }}$ of the last century. By that time the pits had been already dug and local population took oil there for their own needs.

In the Bystrytsa-Nadvirnyanska river basin there have been drilled more than 200 operating wells. There should be mentioned that down that river there is a regional tectonic disturbance, the zone of which is the most mobile during the development of modern tectonic movements.

250 wells are being operated now in the Skhidnytsky oil field. Moreover, there are 632 abandoned wells. Most of the drilling strings and casing strings were not cemented. The location of some abandoned wells is practically unknown. At the same time, we shouldn't exclude the idea that they are the possible ways of hydrocarbon flow from productive beds to the near-surface layers.

Dashavske, Ugerske, Bilche-Volynske and Oparske gasholders have been created on the basis of depleted gas fields, which are mainly developed on gaseous mode. At the time of creation of gasholder objects the covers over them were hermetic. Due to the application of different pressures in beds (strata) and occurrence of extreme conditions (earthquakes) there can be observed the 
violence of joint fissure, breakage of casing cement stone of the well, etc. According to the data of Ukrainian Gas Research Institute, last years the void volume of the Dashavsky gasholder has exceeded twice the critical value, appointed in design.

Considerable hydrocarbon contamination of near-surface layers and groundwaters can be observed very often on the territories of refineries, haulage contractors and other enterprises.

On the basis of long-term investigations of the secondary hydrocarbon gas contamination of the near-surface layers there have been determined that gasochemical investigations occupy the leading place in gasometric control. It has been conditioned, first of all, constant mobility of the gas. Its qualitative and quantitative characteristics are constantly changing in the bowels of the earth with possible bed overflows and creation of the secondary halations of the nearsurface gas contamination at mines and exploration areas. Intensive movement of the gaseous fluids during operative-technogenous processes serves as a basis for the application of gas-geochemical criterion for the assessment of the state of hydrocarbon contamination in near-surface layers. For the differential estimate of the degree of gas contamination in soil on the territories of mines and gas pipelines or some areas of hydrocarbon pollution there can be used ecologicaltechnological classification (Table.1), built on normative documents of the environmental protection.

Selection of methane and propane for the given classification is based on the fact that they are the most suitable for the diagnostic of qualitative and quantitative characteristics of gas contamination halations in shallow beds (to the first from the surface of water bearing horizons) within the frame of the socalled biochemical zone. Determination of methane bearing soil is important as, in most cases, methane creates the main background for hydrocarbon secondary gas contamination. Since the latter has high diffuse abilities, low sorption properties and little dissolved in water, it is the very active during migration and in the flow that are raising, going ahead of hydrocarbon sinking fraction.

The main migration properties of the oil pollution in natural water are the pollution in the form of lube phase as well as dissolved, soluble and adsorbed oil or oil products. Groundwaters are the first to be polluted by oil products that come from the earth surface by way of infiltration through the aeration zone or by way of distribution in water-bearing horizons. When there is little pollution, the oil products can localize in the aeration zone, not reaching the level of groundwaters. If they reach the level of groundwaters, the horizontal migration can proceed in the form of a separate phase on the surface of subterranean flow and in the soluble or dissolved state with the underground flow. Migration of oil products as a separate phase on the surface is less dangerous than in the soluble or dissolved state with the underground flow, because the dissolved form is distributed on big distances. The most dangerous for the pollution of groundwater are oil and oil products that have low viscosity and high solubility. 
There should be mentioned that method selection for the analysis of oil products in underground and groundwaters has been done, first of all, according to the rules of sanitation. The concentration bounds of oil products in natural water waves from grams to milligrams; they are also determined by the existence of oil product in the form of a separate phase. For economic water supply the intervals for maximum permissible concentration for oil and some oil products are accepted within 0,01-0,3 mg/l (Table.2)

Table.1

\section{Ecological-technological classification of halations of gas contamination in near-surface beds}

\begin{tabular}{|c|c|c|l|l|}
\hline \multirow{2}{*}{ Degree } & \multicolumn{2}{|c|}{$\begin{array}{c}\text { Percentage of gaseous } \\
\text { mixture composition, \% }\end{array}$} & \multicolumn{2}{|c|}{$\begin{array}{c}\text { Determination of the exploitation safety of the } \\
\text { halations in gas contamination conditions }\end{array}$} \\
\cline { 2 - 5 } & Methane & Propane & \multicolumn{1}{|c|}{ Technological } & Ecological \\
\hline 1. & $0.026-0.1$ & $0.001-0.02$ & Low-background & Steady dangerous \\
\hline 2. & $0.101-0.2$ & $0.01-0.025$ & Middle-background & Tolerance \\
\hline 3. & $0.251-0.5$ & $0.01-0.025$ & High-background & Tolerance conditioned \\
\hline 4. & $0.501-0.7$ & $0.051-0.1$ & Boundary-technological & Tolerance limited \\
\hline 5. & $0.701-1.0$ & $0.101-0.2$ & Abnormal- technological & Low-hazard \\
\hline 6. & $1.001-3.0$ & $0.201-1.8$ & $\begin{array}{l}\text { Highly abnormal- tech- } \\
\text { nological (highly explosive) }\end{array}$ & Dangerous \\
\hline 7. & $3.001-14$ & $1.801-9.5$ & $\begin{array}{l}\text { Emergency- technological } \\
\text { (highly explosive) }\end{array}$ & Dangerous \\
\hline 8. & $<14.901$ & $<9.501$ & $\begin{array}{l}\text { Highly emergency- } \\
\text { technological }\end{array}$ & Very dangerous \\
\hline
\end{tabular}

Table 2

Boundary permissible concentration of oil and oil products in the sources of economic and protable water supply.

\begin{tabular}{|l|c|l|c|}
\hline \multicolumn{1}{|c|}{ Component } & $\begin{array}{c}\text { Boundary permissible } \\
\text { concentration, mg/l }\end{array}$ & \multicolumn{1}{c|}{ Component } & $\begin{array}{c}\text { Boundary permissible } \\
\text { concentration, mg/l }\end{array}$ \\
\hline Sulfur-bearing oil & 1.0 & Light kerosene & 0.05 \\
\hline Other oil & 0.3 & Oxygenic kerosene & 0.01 \\
\hline Petrol & 0.1 & Industrial kerosene & 0.01 \\
\hline Kerosene & 0.1 & Tractor fuel kerosene & 0.01 \\
\hline Sulfurized kerosene & 0.1 & & \\
\hline
\end{tabular}

Protection measures of groundwater from petroleum pollution may be divided into three groups: excavation of polluted rocks of water bearing horizon; methods of pollution polarizing and hydrodynamic methods.

Excavation of polluted rocks includes excavating and transporting soil to the safe place where it will be buried according to the standards of environmental protection. This method is the most effective when the product doesn't reach the level of groundwaters. This method requires rather big capital outlays. 
A considerable application has hydrodynamic measures of protection that include shrinking of oil lens from the surface of ground waters, extraction oil product to the surface, interception of the polluted flow of ground waters and depuration of water bearing horizon from oil. These methods are rather simple and mobile in their usage. When the depth of the groundwater level is not very big (less than $3.0 \mathrm{~m}$ from the surface), the interception of oil products can be done with the help of a ditch. The ditch is also effective when the groundwater level is intercepted. Moreover, the measures of hydrodynamic protection of the groundwater from oil pollution can be done with the help of drain holes. They include pumping of polluted water, sometimes in big quantities. That is why very often we speak about the usage of this water, its purification or utilization. Preliminarily water purification from emulsified or film oil products can be done at the place of purifying measures. For this purpose we usually use natural sorbents (sawdust, dry peat), industrial waste (ash), artificial sorbents received in the conditions of industrial production.

Another way of hydrodynamic protection of groundwater from oil pollution is the hydraulic curtain. This method consists of pumping the polluted water and oil with further water infusion higher within the area of contamination with the help of injection wells. This protection method reduces the quantity of polluted water and increases the purification level of water bearing horizon. It also creates a hydraulic barrier on the way of ground waters. The application area of hydraulic curtains is determined by filtration properties of water bearing beds. The filtration coefficient should be less than $10 \mathrm{~m}$ per day.

To improve the water quality of water bearing horizon polluted by oil products there can be used microorganisms, the activity of which will lead to the biological degradation of organic compounds.

Taking into consideration significant ecological risk during the process of exploitation of oil and gas fields there has been done the assessment of their influence on natural environment with the emphasis on ecological safety of new fields that are put into operation.

The next assessment stage of the influence of oil and gas fields that are used in refineries on geological and contiguous environments should be the ecological monitoring of oil and gas industry with the emphasis on ecological safety of operation of fields, refineries and objects of oil and gas transportation.

The main methods used at monitoring are distant, noncontact and instrumental. The aim of realization of the above mentioned methods is to make a forecast of emergency situations. 